Mechanical Properties of Bamboo 


\section{FORESTRY SCIENCES}

Volume 37

The titles published in this series are listed at the end of this volume. 


\title{
Mechanical Properties of Bamboo
}

\author{
JULES J.A. JANSSEN \\ Eindhoven University of Technology \\ Faculty of Architecture and Building \\ Eindhoven, The Netherlands
}

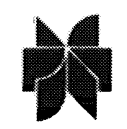

Springer Science+Business Media, B.V. 


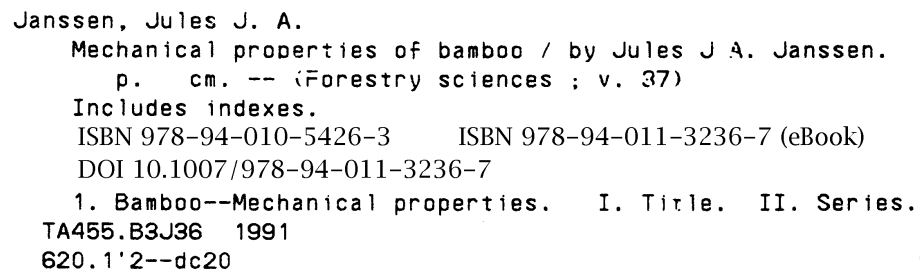

Printed on acid-free paper
All Rights Reserved
(C) 1991 Springer Science+Business Media Dordrecht
Originally published by Kluwer Academic Publishers in 1991
Softcover reprint of the hardcover 1st edition 1991
No part of the material protected by this copyright notice may be reproduced or utilized in any form or by any means, electronic or mechanical, including photocopying, recording or by any information storage and retrieval system, without written permission from the copyright owner. 


\section{Contents}

Preface

Chapter 1: Growth and anatomy

vii

Chapter 2: Thermal expansion

Chapter 3: Moisture content and mass per volume

Chapter 4: Chemistry

12

Chapter 5: Elasticity

Chapter 6: Bending

Chapter 7: Compression

Chapter 8: Shear

62

Chapter 9: Tension

Chapter 10: Torsion

102

Chapter 11: Relations between properties

List of symbols

Author index

Keyword index

131

Keyword index (relations between properties) 


\section{Preface}

In this book I have collected many reports on the properties of bamboo. Since I started bamboo research in 1974, I have collected many publications on bamboo. However, in contacts with other researchers I became aware of the fact that several of these publications were unknown to them. Consequently their activities in research or in bamboo projects had to start at a lower level than if they had known some of these publications. Therefore, I discussed the need for a book like this with several colleagues, and I decided to start writing.

In this book I present data on properties, as published by researchers. Certainly it is not complete; e.g. the proceedings of the bamboo workshop in Cochin in November 1988 are not included; they arrived just too late to be taken into account. On the other hand, in writing this preface I realize I have forgotten my own thesis. I do apologize to any colleague whose relevant report is not taken into account as well.

I like to express my feelings of respect to the board of my faculty: they allowed me to spend so much time on this book, and they gave a considerable financial support for the printing costs.

In my opinion bamboo should become a completely normal building material, just as timber, steel or concrete. I realize it is still a long way to go to reach this purpose. I hope this book is a small step on that way. I would appreciate if the reader is so kind to send me his comments.

Eindhoven, January 1991

Jules J.A. Janssen 